\title{
Developing an Android-Based Guidebook to Dragonflies and Butterflies
}

\author{
Susanti Murwitaningsih ${ }^{1, a)}$, Maryanti Setyaningsih ${ }^{1}$, Dimas Putra Sandajaja $^{2}$ \\ ${ }^{1}$ Biology Education Department, University of Muhammadiyah Prof. Dr, HAMKA, Jakarta, 12130, Indonesia \\ ${ }^{2}$ Physics Education Department, Universitas Muhammadiyah Prof. Dr, HAMKA, Jakarta, 12130, Indonesia \\ a) Corresponding author: murwitaningsih@uhamka.ac.id
}

\begin{abstract}
Dragonflies (Odonata) and butterflies (Lepidoptera) play very important roles in the ecosystem and there are a great many of them. It is estimated that there are more than 5,000 types of dragonflies and 17,500 types of butterflies in the world, among them around 800-1,000 types of dragonflies and 2,200-3,000 types of butterflies can be found in Indonesia. A series of observations conducted in July 2018 at the Cibodas Botanical Garden in West Java found 8 species of dragonflies and 33 species of butterflies. The aim of this research is to develop an Android-based mobile guidebook application for dragonfly and butterfly observation that can be used at any time to easily identify dragonflies and butterflies. This research is a development research that refers to the 4D development model. In the Define stage, activities were carried out to collect initial information related to the diversity of dragonflies and butterflies. In the Design stage, activities were carried out to design books and Android applications. In the Develop stage, validation activities were carried out by dragonfly and butterfly experts, as well as media experts using questionnaires, interviews and discussions (FGD). In the Disseminate stage, activities were carried out to test an android application on students of the Biology Education Department at FKIP UHAMKA. The data obtained were analyzed using quantitative and qualitative descriptive techniques. The test results show that the guidebook was assessed as very good on the presentation aspect, very good for the material and good for the language, with a score of $88 \%, 85 \%$ and $82 \%$, respectively. Thus, this mobile guidebook application, called ODOLEPI, is feasible for use in the observation of dragonflies and butterflies.
\end{abstract}

Keywords: Dragonfly, Butterfly, Guidebook, Android.

\section{INTRODUCTION}

Arif. S. Sadiman says that learning is a complex process that occurs in every person troughout his/her life. One of the signs that a learning process has occured in a person is a change in their behaviour, whether it is in their cognitive, psychomotor, or affective domain [1]. The hope is that these changes that occur due to a learning process are for the better, so that he/she may be able to differentiate between what is good and what is evil in their life.

In the learning process, we need learning resources. One of those resources are educators. According to Arif.
S. Sadiman, education emerged as a profession due to parents' limitiations in teaching knowledge, skills and attitude to their children [1]. Education has continued to evolve over the years and in this day and age, teachers are not the sole learning resources available. The roles of teachers in the modern era that is today is more as a faciliator and mediator for students in their learning process [2]. Hence, students nowadays need other complementary learning resources or tools in order to make the learning process more effective and fun.

It is estimated that there are more than 5,000 types of dragonflies and 17,500 types of butterflies in the world. In Indonesia alone, scientiests have identified around 
800-1,000 types of dragonflies and 2,200-3,000 types of butterflies $[3,4]$. The numbers show that Indonesia has a great diversity of dragonflies and butterflies. A series of observations conducted in July 2018 at the Cibodas Botanical Garden in West Java found 33 species of butterflies and 8 species of dragonflies [5, 6].

Dragonflies and butterflies are two insects that play important roles in their ecosystem $[3,4,7,8]$. Therefore, we have to protect and study them. Although these animals are abundant in numbers and although they are recognised as valuable environmental indicators, we found that, after an assessment and interviews with science and biology teachers and vice principals of curriculum in a number of junior and senior high schools around the Cibodas Botanical Garden, and after assessing the questionnaires that we gave out to students in the same schools, both students and teachers in those schools were yet to make use of the potential learning resources, although they were readily available. This is due to the lack of readily available information on the diversity of dragonflies and butterflies, as well as the lack of a guidebook that is easy to use on the observation and identification of dragonflies and butterflies.

In order to provide students with a fun and engaging learning atmosphere, an appropriate learning tool is needed. I today's era of information technology, we are seeing how quickly technology is advancing and how information is easily obtainable from anywhere using a gadget and the internet. Technology, in particular information technology, is heavily affecting the way humans are learning and obtaining information and knowledge. Information technology can act as a learning tool that is purposedly designed and developed to transfer information and knowledge to the public or audience [9]. To that end, we developed a mobile application that informs its users on the diversity of dragonflies and butterflies and how to conduct an observation of the animals. The mobile application is intended for use by students in various levels of education as, based on a survey that we conducted, the subject of diversity is included in the curriculum of various levels of education,from primary to higher education, particularly in biology classes.

\section{METHOD}

This research is a development research, or also known as research and development $(\mathrm{RnD})$ that aims to improve the instructional design, development, and evaluation process based on specific problem-solving situations or generalized examination procedures. This research uses the 4D development model that comprises 4 stages, Define, Design, Develop, and Disseminate. Validation is conducted by interviews and discussions with experts on dragonflies and butterflies, as well as with media experts. In the Disseminate stage, the mobile application was tested on students at the Universitas Muhammadiyah Dr. Hamka's Department of Biology Education and assessed using a questionnaire. The validation instrument was developed using the Likert scale (1-5). We then calculated the raw data using equation 1 [11].

$$
N P=\frac{R}{S M} \times 100
$$

$$
\begin{aligned}
& \text { Keterangan: } \\
& \mathrm{NP} \quad=\text { nilai persen yang dicari atau diharapkan } \\
& \mathrm{R} \quad \text { = skor mentah yang diperoleh siswa } \\
& \mathrm{SM} \quad=\text { skor maksimum ideal dari tes yang } \\
& \text { bersangkutan } \\
& 100 \quad=\text { bilangan tetap }
\end{aligned}
$$

The result of the assessment can then be converted into letter grade, weight, and grade description as seen in Table 3.5 Assessment Percentage [11].

Table 1. Assessment Percentage

\begin{tabular}{cccc}
\hline Mastery Level & Letter Grade & Weight & $\begin{array}{c}\text { Grade } \\
\text { Description }\end{array}$ \\
\hline 86 up to $100 \%$ & A & 4 & Very good \\
76 up to $85 \%$ & B & 3 & Good \\
60 up to $75 \%$ & C & 2 & Average \\
55 up to $59 \%$ & D & 1 & Poor \\
$\leq 54 \%$ & TL & 0 & Very poor \\
\hline
\end{tabular}




\section{RESULTS}

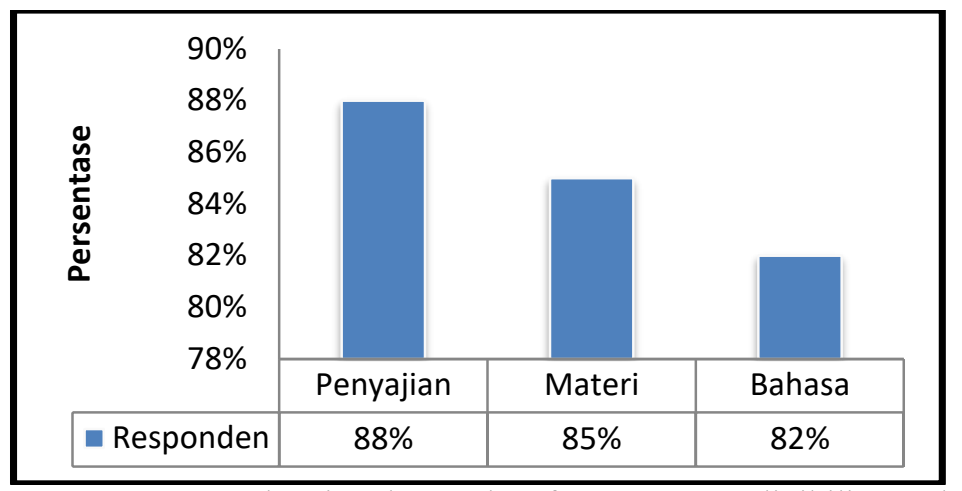

Figure 1 . A chart showing the results of ODOLEPI's eligibility study

This development research resulted in a learning tool in the form of an Android-based e-book that we call ODOLEPI, an acronym of "Odonata and Lepidoptera". This Android mobile application was created based on the book "Menghadirkan Capung dan Kupu-kupu Sebagai Sumber Belajar" ("Presenting Dragonflies and Butterflies as Learning Resources"), which has previously been validated by experts and assessed by respondents. The development of the app aims to make it easy for users to access a guidebook on dragonfly and butterfly observation and identification. This research is relevant to the study conducted by Aristoteles [4], Hening $\mathrm{T}$ Rachman [12], and Faiqoh Islamadina [13]. The difference between this research and other similar research is in the concept; this research focuses on dragonflies and butterflies in the Cibodas Botanical Garden, West Java. Furthermore, the difference can also be found in the design stage and development technique of the app, which uses MIT App Inventor 2. MIT App Inventor 2 is a tool for developing Android applications. It requires no programming skills, which can only be attained through mastering complicated programming languages. By using this tool, students and teachers alike can easily develop the application [14].

\subsection{Product Implementation}

The research team then enhanced the quality of the product, ODOLEPI, based on the directions, comments and suggestions from the experts that we consulted and implemented them in a small-scale testing of the product on the students of the Department of Biology Education. The implementation process was conducted by letting each student, as a respondent, try out the ODOLEPI Android application. The respondents then scored the ODOLEPI application using the validation instrument that had previously been handed out to them. Figure 1 shows a chart of the results of ODOLEPI's eligibility study.
From the chart we can see that ODOLEPI was assessed as "Very good" on its presentation aspect and "Good" on the aspects of material and language. Using the assessment percentage shown in Figure 1, we can then calculate the average score from the respondents, is at $86 \%$, which placed ODOLEPI in the "Good" category. From this assessment, we can conclude that ODOLEPI is eligible for use.

\subsection{End Product}

The learning tool that the research team developed is an Android application containing a guidebook on dragonflies and butterflies. The topics covered in the guidebook include introduction, morphology, differences between the males and females, life cycles, observation techniques, and the taxonomy of dragonflies and butterflies. The Android application that was produced was named ODOLEPI. ODOLEPI is a representation of the book titled "Menghadirkan Capung dan Kupu-kupu Sebagai Sumber Belajar" ("Presenting Dragonflies and Butterflies as Learning Resources"). Figure 2(a) to 2(f) shows some of ODOLEPI's user interfaces. 


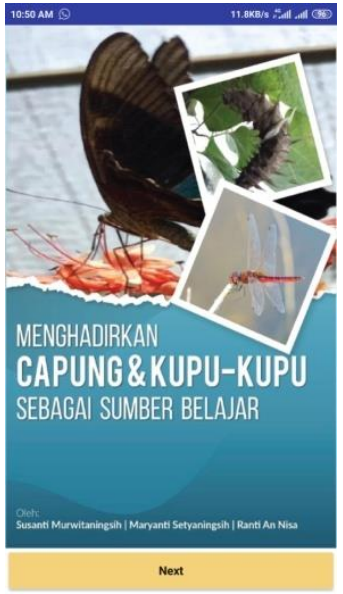

(a)

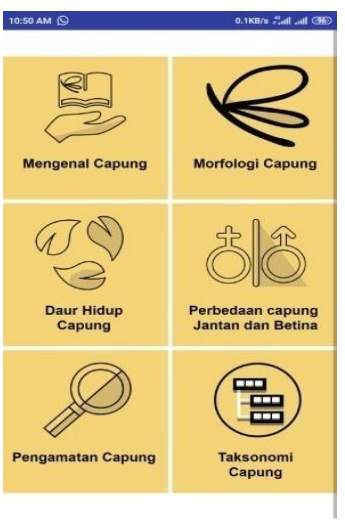

(c)

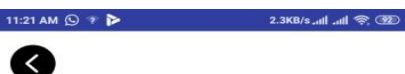

Taksonomi Capung

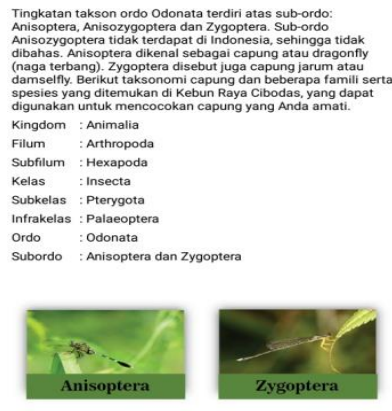

(e)

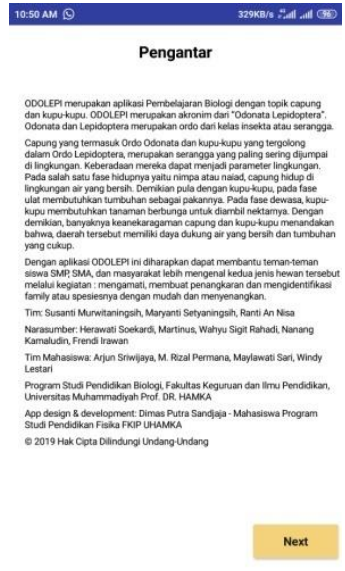

(b)

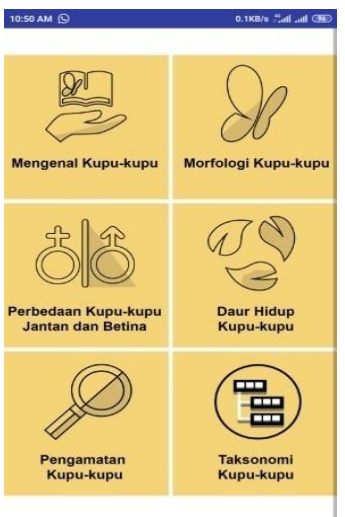

(d)

(?

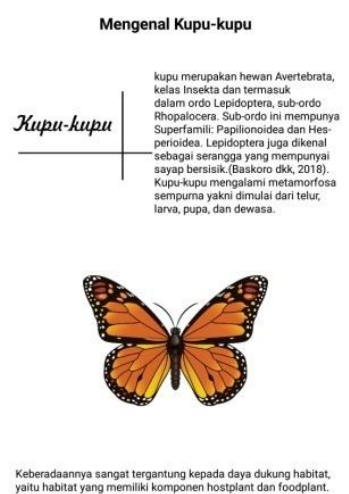

(f)

FIGURE 2. Some of ODOLEPI's User Interfaces (a) ODOLEPI's home screen, (b) ODOLEPI's introduction screen, (c) a list of menu in the ODOLEPI app that covers dragonflies, (d) a list of menu in the ODOLEPI app that covers butterflies, (e) information screen in the "Dragonfly Taxonomy" menu, (f) information screen in the "Introducing the Butterflies" menu. 


\section{DISCUSSION}

ODOLEPI is a technological innovation in education that utilizes technological development. This app is available offline and can be accessed anytime, anywhere by anyone who downloads it from the Google Play Store. Using an Android app as a learning tool makes learning easier, more efficient, and more engaging and therefore will improve students' motivation to learn.

\section{CONCLUSION}

The android-based guidebook on dragonflies and butterflies that the research team developed can be used as learning resources that support students' learning process. This learning tool can also be used as a teaching tool in the classroom or as a personal learning tool as it has undergone expert validation. This learning tool is more efficient and it makes the learning process easier for both educators and students thanks to its various features, engaging user interfaces, portability, and the fact that, unlike conventional books, it does not have to be carried around everywhere.

\section{ACKNOWLEDGMENT}

We would like to express our gratitude to UHAMKA's Research Bureau, in particular its distinguished chairman Prof. Dr. Hj. Suswandari, M.Pd, who has given us her full support in this research. The research is also a part of a research that was granted by the Indonesian Ministry of Research, Technology, and Higher Education and therefore we would like to extend our gratitude to the ministry for facilitating this research. We would also like to thank the head of the Indonesian Institute of Sciences (LIPI) Cibodas Office and his wonderful staff that has granted us the permit to conduct our research in the Cibodas Botanical Garden.

\section{REFERENCES}

[1] Sadiman, Arief S. Media Pendidikan, Pengertian, Pengembangan, dan Pemanfaatannya. Jakarta: Rajawali Pers, 2016.

[2] Purnama, Ragil P. \& Marsudi. Pengembangan Media Pembelajaran IPA Materi Metamorfosis Berbentuk Video Dua Dimensi Pada SDI Little Camel Mojokerto. Jurnal Seni Rupa. 05(03): 433454, 2017.

[3] Murwitaningsih, Susanti, dkk. Menghadirkan Capung dan Kupu-kupu Sebagai Sumber Belajar. Jakarta: UHAMKA Press. ISBN: 978-602-107894-5, 2019.
[4] Aristoteles, dkk. Panduan Lapangan Jenis Kupukupu di Lingkungan Universitas Lampung Berbasis Android. Ilmu Komputer Unila Publishing Network all right reserve. 6(1): 64-74, 2018.

[5] Murwitaningsih, Susanti, dkk. 2020. Study of Butterfly Diversity in Botanical Garden Indonesia. Internasional Journal of Psychosocial Rehabilitation. 24(8): 2271-2277

[6] Murwitaningsih, Susanti, dkk. 2019. Dragonfly Diversity in Cibodas Botanical Garden in West Java. Biotropic. 3(1): 62-67

[7] Mas'ud, Abdu, dkk. Keanekaragaman Kupu Family Papilionidae (Pappilio Ulyses dan Ornithoptera Croesus) Pada Berbagai Ketinggian Tempat di Cagar Alam Gunung Sibela Pulau Bacan. Proceeding Seminar Biodiversitas. 237243, 2016.

[8] Lamatoa, Derby C, dkk. Populasi Kupu-kupu (Lepidoptera) di Pulau Mantehage, Sulawesi Utara. Jurnal Ilmiah Sains. 13(1): 52-56, 2013.

[9] Pribadi, Benny. Media \& Teknologi dalam Pembelajaran. Jakarta: Kencana, 2017.

[10] Setyosari, Punaji. Metode Penelitian Pendidikan \& Pengembangan. Jakarta: Prenadamedia, 2013.

[11] Purwanto, Ngalim. Prinsip-prinsip dan Teknik Evaluasi Pengajaran. Bandung: Remaja Rosda Karya Offset, 2013.

[12] Rachman, Hening T, dkk. 2017. Penyusunan Panduan Identifikasi Spesies Capung Berdasarkan Penelitian Keanekaragaman Capung di Rawa Jombor Klaten. Jurnal Prodi Pendidikan Biologi 6(7): 435-446

[13] Islamadina, Faiqoh. 2016. Validitas Kepraktisan dan Kefektifan Aplikasi Media Mobile Learning "Panduan Kupu-kupu" Berbasis Android Untuk Siswa Kelas X SMA. BioEdu. 5(3): 352-360

[14] Mulyana, Eueung. 2012. App Inventor: Ciptakan Sendiri Aplikasi Androidmu. Yogyakarta: ANDI 